\title{
Artur Szutta
}

Uniwersytet Gdański

\section{Robert Kryński}

Katolicki Uniwersytet Lubelski

\section{Co z tą filozofią? Słów kilka na temat pewnej inicjatywy}

W tekście przedstawiono kontekst i powody, które doprowadziły nas do idei założenia Ruchu na rzecz Filozofii oraz popularyzującego filozofię czasopisma „Filozofuj!”. Nasza wypowiedź przyjmie formę dialogu. W zaprezentowanej poniżej rozmowie uczestniczą dwaj koledzy z uniwersytetu: Kazimierz, filozof i Sekstus, akademik-niefilozof, raczej sceptyczny co do wszelkich programów ratowania filozofii. Spotykają się w dogodnym do prowadzenia rozmowy miejscu - na przykład w uniwersyteckiej kawiarni. Zamówiwszy małą czarną (to sceptyk) i herbatę (filozof), siedzą przy stoliku. Rozpoczyna Sekstus.

S: Kaziu, słyszałem, że coraz mniej studentów na tej waszej filozofii.

K: Nie da się ukryć, Sekstusie, ubywa nam chętnych do studiowania. Obawiam się nawet, że już za kilka lat $\mathrm{z}$ wielu polskich uczelni kierunek studiów filozoficznych może zniknąć, bo nikt nie będzie chciał studiować filozofii.

S: Obawiasz się, bo jesteś nauczycielem akademickim. Tymczasem wielu powiada: najwyżej niektórzy stracą pracę. Śmierć filozofii akademickiej nie musi oznaczać śmierci filozofii jako takiej. Bywało nawet, że to, co najwartościowsze w filozofii, powstawało poza uniwersytetem. Pomyśl choćby o Kartezjuszu, Pascalu, Malebranche’u, Spinozie czy Leibnizu.

K: Nie przeczę, praca na uczelni daje mi dużo satysfakcji. Jednak nie boję się bezrobocia. Myślę, że znalazłbym jakiś sposób na życie, może nawet bardziej dostatnie niż obecnie. Niemniej, nie wyobrażam sobie, aby uprawianie filozofii na wysokim poziomie poza uczelnią było dzisiaj możliwe.

S: Dlaczego tak uważasz? 
K: Ta dyscyplina, zresztą jak każda, wymaga dużo czasu i pracy. Gdybym musiał jednocześnie martwić się o zapewnienie sobie i swojej rodzinie warunków materialnych i filozofować, to nie robiłbym dobrze ani jednego, ani drugiego. Pewnie, w poczuciu odpowiedzialności za rodzinę, wybrałbym to pierwsze.

S: Widzę, że wątpisz w możliwość zostania drugim Kartezjuszem?

K: Sekstusie, rozkwit filozofii poza murami uniwersytetów za czasów Kartezjusza był możliwy również dzięki temu, że były to czasy mecenasów, których dzisiaj, zauważ, ze świecą szukać. Tymczasem uprawianie filozofii - od samego jej zarania - wymagało i wymaga wolności od trosk materialnych. Jeśli ani uniwersytet, ani bezinteresowny mecenas nie wspierają filozofa, to - o ile ten drugi nie jest człowiekiem bogatym lub gotowym na życie pustelnika - ma on do wyboru dwie drogi: zmienić zawód albo uprawiać filozofię komercyjną, czyli stać się trochę sofistą.

S: Czyli kim? Kogo nazywasz sofistą, Kaziu?

K: Sofista-filozof komercyjny to ktoś, kto nie szuka prawdy, ale tego, co da się sprzedać, na czym da się zarobić. Nie mam wątpliwości, że zniknięcie filozofii z uniwersytetu oznaczałoby, jeśli nie śmierć, to upadek filozofii jako dyscypliny naukowej.

S: Chcesz powiedzieć, że na filozofii nie da się zarobić? A mnie się wydaje, że jeśli produkt jest dobry, to na nim można zarobić. Poza tym, nie bardzo rozumiem, co złego jest na przykład w pisaniu książek, które będą kupowały rzesze czytelników.

K: Zgoda, ale zysk finansowy nie powinien być podstawowym celem uprawiania filozofii. Filozofia - z definicji - jest poszukiwaniem prawdy, nawet jeśli takie poszukiwania prowadziły filozofa pod prąd. Jeśli byt materialny filozofa będzie zależał od tego, czy istnieje dostatecznie dużo chętnych do czytania jego prac, gotowych za nie zapłacić, to istnieje niebezpieczeństwo, że filozof stanie się niewolnikiem swoich czytelników, będzie starał się w swoich pracach dostosować do ich oczekiwań, nawet kosztem prawdy. A niektóre prawdy mogą być niepopularne.

S: Niewolnikiem, powiadasz? Przecież zawsze było tak, że o wolności filozof mógł tylko pomarzyć, o ile sam nie był zamożnym człowiekiem. Spójrz Kaziu, przecież zawsze jest się od kogoś zależnym: od mecenasa, państwa lub czytelników. $Z$ tej trójki na moich ciemiężców najchętniej wybrałbym czytelników.

K: Jest jeszcze jeden powód, Sekstusie, dla którego lepiej byłoby, aby filozofia przetrwała na uniwersytetach. Aby go lepiej przedstawić, ucieknę się do metafory wspinaczki. W filozoficznych dociekaniach niejako wspi- 
namy się coraz wyżej i wyżej, aby coraz więcej dojrzeć. Jeśli ktoś zawodowo zastanawia się nad jakąś filozoficzną kwestią, na przykład problemem świadomości, przechodzi długą, żmudną drogę zaznajamiania się z dotychczasową literaturą, i jeśli robi krok dalej, to czyni to z miejsca, do którego musiał dotrzeć drogą żmudnej lektury i refleksji. Jeśli czytelnik chciałby tam pójść za filozofem, też musiałby dokonać wysiłku. Owszem, nie tak wielkiego, jak autor tekstu, ale jednak wysiłku, do którego nie ma wielu chętnych. Wątpię, czy pisząc tak zaawansowane teksty filozof mógłby znaleźć dość czytelników, aby wyżywić rodzinę. O jakimś bardziej spektakularnym sukcesie finansowym nawet nie wspomnę.

S: No cóż, Kaziu, skoro na taką „wysokogórską” filozofię nie ma zapotrzebowania, nikt nie chce jej studiować, więc może musi umrzeć. I byłaby to śmierć naturalna, rezultat darwinizmu czy mechanizmów wolnorynkowych w świecie akademickim. Może nic w tym złego?

K: O! Widzę, że jesteś zwolennikiem wolnego rynku, Sekstusie. Moim zdaniem, jednak z faktu, iż coraz mniej osób dostrzega wartość filozofii, nie wynika, że ona traci na wartości. Śmierć filozofii byłaby niepowetowaną stratą także dla tych, którzy nie umieją dostrzec jej wagi. Jeśli spojrzeć nawet na te wartości, które są dziś powszechnie uznawane: technologia, nauka, demokracja, to okazuje się, że mają one swoje źródło w dociekaniach filozoficznych. Jeśli odetniemy to od tego źródła inspiracji, to można spodziewać się cywilizacyjnego zastoju, a nawet tego, że i nasze dzisiejsze osiągnięcia wymkną nam się z rąk. Odhumanizowana technologia może stać się dla nas zagrożeniem, nie tylko ekologicznym, zaś demokracja to bardzo delikatny twór, jeśli zabraknie w niej obywatelskiego ducha, czerpiącego przecież tyle z filozofii, może łatwo zmienić się w swoją tyrańską karykaturę.

S: Kaziu, niezmiennie mnie zadziwiasz tymi „filozoficznymi paradoksami”. Skoro, jak mówisz, filozofia ma tak dużą wartość, to wytłumacz mi, proszę, dlaczego jej kondycja akademicka jest tak słaba?

K: Już odpowiadam. Zacznę od tego, dlaczego jest coraz mniej kandydatów na studia. Otóż filozofia nie kojarzy się z żadnym zawodem dającym sukces finansowy. Pamiętam, że kiedy sam, w całkiem innych czasach, zdecydowałem się na studia filozoficzne, znajomi pytali, „człowieku, co ty będziesz jadł po filozofii?”. Dziś ten sposób myślenia przybiera na sile. Co więcej, rządzi on nie tylko wyobraźnią młodych ludzi wybierających studia, ale determinuje także myślenie tych, którzy, jak na przykład rząd, swoimi decyzjami wpływają na kondycję dyscyplin akademickich, w tym filozofii. Dla naszych „reformatorów” liczą się szybkie efekty w po- 
staci rosnącego $\mathrm{PKB}$, traktują oni naukę jak inwestycję, która ma przynieść szybkie zyski, najlepiej już dziś. Przy takiej krótkowzroczności nie potrafią dojrzeć, jak ważna jest filozofia (a nawet cała humanistyka) dla życia narodu. Stąd proponują zmiany w szkolnictwie, które będą eliminować takie dyscypliny, jak filozofia.

S: Czy chcesz powiedzieć, że problem sprowadza się jedynie do tego, że mamy materialistycznie nastawione społeczeństwo i rząd skoncentrowany jedynie na czynnikach ekonomicznych?

K: Masz rację, Sekstusie, sprawa jest bardziej złożona, musisz jednak przyznać, że społeczeństwo jest „wychowywane” w duchu, który filozofii nie sprzyja. Młody człowiek, który mógłby wybrać filozofię, nawet nie wie, że taka dyscyplina istnieje. Nie uczą jej w szkole, nie ma czasopism popularnofilozoficznych, nie usłyszy o niej w radiu ani w telewizji, z których sączy się raczej pochwała konsumpcji, kult posiadania dla samego posiadania oraz ideał bezrefleksyjnego korzystania z życia. Filozofii tam nie ma, nie licząc oczywiście wyjątków, stanowiących kroplę jednak w morzu. No i powiedzeń - te nawet na pewno słyszałeś często - jak: „Nie filozofuj mi tu!” albo „Przestań filozofować, zrób coś”. Co prawda, kiedy ja byłem licealistą, z filozofią też trudno (może nawet trudniej) było się spotkać, ale ówczesna Polska mniej kusiła rynkowym sukcesem, nie wciągała w wyścig szczurów, siłą rozpędu na wyobraźnię młodych ludzi miał jeszcze wpływ etos inteligencji walczącej z komunizmem i dlatego, choć słabo znana, filozofia mogła jeszcze kojarzyć się z czymś ważnym, wartym studiowania.

S: Coś mi się zdaje, że filozofowie nie są tu bez winy. Nawet jeśli rozprawiają o problemach życiowych, dotyczących niby każdego, to robią to w tak skomplikowany sposób, przy użyciu takiego języka, że niefilozofom trudno z tej nauki coś wynieść dla siebie, nie wspominając o możliwości wciągnięcia się w filozoficzną lekturę. Ludzie was nie rozumieją. Kaziu, może ta wasza mowa jest zbyt ciemna?

K: Nie przeczę, język filozoficzny jest trudny, niełatwo wniknąć w znaczenia terminów technicznych. Niemniej, zgodzisz się chyba, mój drogi Sekstusie, że tak jest również $\mathrm{w}$ innych dyscyplinach, na przykład w fizyce, biologii czy chemii. Od pewnej hermetyczności nie da się uciec. Ale w jednym przyznam ci rację. Reprezentanci akademickiej filozofii robią niewiele, aby ten ich hermetyczny język przybliżyć niefilozofom, aby ich filozofią zainteresować. Grzechów zaniedbania jest kilka. Zacznę od zajęć z filozofii dla studentów innych kierunków. Tego typu zajęcia często traktowane są jako „zesłanie”. Prowadzący chcą je „mieć za sobą” jak najmniejszym nakładem 
sił. Ograniczają się do historycznego zarysu, od Platona do... którego filozofa zdążą, zarzucając przy tym słuchaczy formułkami, „,izmami”, na jednym tonie, bez zachęcania do dyskusji. Jeden z moich studentów przeprowadził niedawno małe badanie socjologiczne na swoich znajomych studentach niefilozofach. Zadał im pytanie, czy podobały im się zajęcia z filozofii. Wynik (na kilkanaście osób) był taki, że tylko jedna osoba, student seminarium duchownego, miała miłe wspomnienia. Grzech drugi to brak popularyzującego filozofię czasopisma. Być może to grzech największy. Jak wychować sobie przyszłych kandydatów na studia filozoficzne, skoro nie wychodzimy z żadną atrakcyjną ofertą do młodzieży?

S: Pewnie można by jeszcze kilka „grzechów” wskazać, ale z tego, co mówisz, wnioskuję, że pierwszy grzech niełatwo będzie wyeliminować. Chyba że co nie jest mało prawdopodobne - filozofowie w ogóle stracą zajęcia usługowe. Takie rozwiązanie by was, jak sądzę, nie ucieszyło. W przypadku zaś grzechu drugiego moglibyście, „miłośnicy mądrości”, coś zrobić. Dziwię się, że takiego czasopismo nie macie.

K: W pierwszym przypadku można apelować do dyrektorów instytutów i samych prowadzących zajęcia, aby starali się je prowadzić w bardziej atrakcyjnej formie. Zmusić nikogo odgórnie jednak nie można. W sprawie czasopisma masz rację, Sekstusie. To ogromne zaniedbanie środowiska filozoficznego. Takie pismo powinno od dawna funkcjonować. Jest jednak nadzieje, że wkrótce zaistnieje. Rozmawiałem niedawno z dwoma młodymi filozofami, którzy podjęli taką inicjatywę. O ile mnie pamięć nie myli, czasopismo ma się nazywać „Filozofuj!”.

S: Dziwna nazwa. Taki imperatyw, rozkaz. Nie brzmi zachęcająco. Skąd taki pomysł na tytuł?

K: Zapytałem ich, dlaczego nie „Umysł” albo „Myśl”, „Filozofia i Życie” coś, co brzmiałoby bardziej profesjonalnie.

S: I co ci powiedzieli?

K: Że to swojego rodzaju protest, próba przełamania stereotypu, który doskonale obrazuje wspomniane przeze mnie powiedzenie „Nie filozofuj mi tu!”. Oni chcą iść pod prąd i namawiać wszystkich, aby właśnie filozofowali. Mam nadzieję, że im się uda. Chętnie do nich dołączę.

S: Kaziu, jakoś nie widzę powodów do optymizmu. Czy nie jest prawdą, że o idei takiego czasopisma filozofowie rozprawiają już od dłuższego czasu. Nawet, o ile mnie pamięć nie myli, już takie próby miały miejsce. Wyszedł jeden numer czasopisma. Jak ono się nazywało? Poświęcone filozofii umysłu. Nawet pięknie ilustrowany i ciekawy - rzeczywiście na poziomie 
„Wiedzy i Życie”. Skończyło się jednak na tym jednym numerze, może dwóch, nie pamiętam.

K: Owszem, pomysł wymaga szerszego wsparcia. Współpracy całego środowiska filozoficznego. Takiego czasopisma nie zrobi garstka osób, a przecież popularyzacja i upowszechnianie filozofii jest żywotnym interesem całego środowiska. To, że na takie czasopismo trzeba było czekać tak długo, pokazuje, że środowisko nie potrafiło podjąć tak ważnych dla siebie działań, zresztą dotyczy to nie tylko popularyzacji filozofii. To z kolei oznacza, że jest podzielone, słabo zintegrowane. Inicjatorzy powstania czasopisma widzą więc problem szerzej. Między innymi dlatego założyli oni Ruch na rzecz Filozofii. Wczoraj widziałem stronę internetową tego ruchu. Zaraz, zaraz jak oni to ujęli. Już określili cele Ruchu w formie postulatów. Po pierwsze, działać na rzecz popularyzacji filozofii. Po drugie, dążyć do integracji środowiska filozoficznego. Jaki był trzeci postulat? Aha, dbać o wysokie standardy uprawiania filozofii i filozoficznego kształcenia. I po czwarte, działać na rzecz kształcenia filozofii w szkołach i na uniwersytetach.

S: Czy zanadto się nie rozpędzili. Samo czasopismo - rozumiem - jest potrzebne, ale cały ten ruch? Czyż nie istnieją już organizacje skupiające wokół siebie filozofów, które takie same cele realizują? Polskie Towarzystwo Filozoficzne na przykład?

K: Owszem istnieją. Nikt też nie twierdzi, że istniejące już towarzystwa filozoficzne, komitety nie spełniają swojej funkcji. Każde jest cenne na swój sposób. Powstanie Ruchu na rzecz Filozofii, jako inicjatywy oddolnej, moim zdaniem, nie stanowi jednak dla nich żadnej konkurencji. W wielu zadaniach taki ruch po prostu wspierałby wysiłki innych organizacji. Myślę też, że wszystkie te postulaty są ze sobą mocno powiązane, a sprawa popularyzacji dla realizacji ich wszystkich wydaje mi się kluczowa.

S: Kaziu, co każe Ci tak myśleć?

K: Już spieszę z wyjaśnieniem, Sekstusie. Przyszłość filozofii w szkołach, ale także na uniwersytetach zależy w dużej mierze od decyzji politycznych, na przykład od tego, czy minister pozwoli na studiowanie filozofii jako drugiego kierunku nieodpłatnie, czy filozofia zostanie uznana jako przedmiot podstawowy w liceum. Decyzje tego rodzaju (jeśli do nich dojdzie) będą wypadkowymi wielu czynników, jednym $\mathrm{z}$ nich z pewnością będzie to, jaki jest obraz filozofii w umysłach polityków, a także w powszechnej opinii społecznej. W tej chwili filozofia kojarzy się większości jako przedmiot dziwaczny i zbędny w procesie edukacji, a także jako przedmiot, którego studiowanie nie daje szans na zawodową karierę. Wszystkie te przekona- 
nia są fałszywe, a uświadomienie Polakom tego jest możliwe jedynie wówczas, gdy filozofowie wyjdą poza swoje hermetyczne środowisko i zaczną dzielić się filozoficznymi osiągnięciami także z zewnętrznym światem. Taki właśnie cel przyświeca Ruchowi na rzecz Filozofii. Twórcy „Filozofuj!" chcą zacząć od popularyzowania filozofii, przekonywania Polaków, że to fascynująca i niezwykle ważna dyscyplina, której problemy są ciekawe i doniosłe, oraz że uprawianie filozofii przemienia, daje umiejętności cenne dla współczesnego społeczeństwa, także dla rynku. Liczą, w czym się do nich przyłączam, że pewnego dnia, dzięki tej inicjatywie na ulicach naszych miast, w szkołach, ministerstwach będzie coraz więcej ludzi, którzy na słowo „filozofia” będą reagowali pozytywnie, pewnego dnia liczba takich ludzi przekroczy masę krytyczną dla powszechnego zrozumienia wagi filozofii, i stanie się cud.

S: Może i jest sens w tym, co mówisz. Może uda się powoli odmienić obraz filozofii w społeczeństwie. Życzę powodzenia.

Sekstus spojrzał na zegarek $i$ westchnał głęboko.

S: No, czas na mnie, studenci czekają!

Sekstus podniósł się i dość szybkim krokiem opuścił kawiarnię, zostawiając filozofa, jak zwykle zamyślonego.

\section{What about this philosophy? A few words about a certain initiative}

\section{SUMMARY}

This paper, written in a form of a dialogue between an advocate of philosophy and its critic, presents a discussion over the condition and value of philosophy in contemporary world. It aims to emphasize the need for supporting and popularizing philosophy in society. This kind of considerations led the author of this paper into founding The Movement for Philosophy and "Philosophize!" Journal.

KeYwORDs: condition and value of philosophy, The Movement for Philosophy. 